\title{
Ultrasonographic findings of the mammary gland, liver, gallbladder, spleen, and kidneys in transgenic goats for hG-CSF during induced lactation
}

\section{Achados ultrassonográficos de glândula mamária, fígado, vesícula biliar, baço e rins de caprinos transgênicos para o hG-CSF durante lactação induzida}

\author{
Francisco Carlos de Sousa ${ }^{1}$; Carlos Henrique Sousa de Melo ${ }^{2}$; \\ Ribrio Ivan Tavares Pereira Batista ${ }^{3}$; Deisy Johana Diaz Sanchez; \\ Joanna Maria Gonçalves Souza-Fabjan ${ }^{5}$; Alexsandra Fernandes Pereira ${ }^{6}$; \\ Luciana Magalhães Melo ${ }^{7}$; Vicente José de Figueirêdo Freitas ${ }^{7}$; \\ Dárcio Ítalo Alves Teixeira ${ }^{7 *}$
}

\begin{abstract}
In transgenic murine models, the study of certain organs or tissues can be performed after euthanasia of some specimens. However, this practice may not be economically feasible when applied to livestock such as transgenic goats. It is necessary to use minimally invasive methods to perform in vivo studies of organs that may be affected by disorders related to the activity of the transgene, particularly during milk production, when the recombinant protein is secreted. The aim of this study was to describe ultrasonographic findings of the liver, gallbladder, spleen, kidneys, and mammary glands in transgenic goats for evaluating the effect of human granulocyte-colony stimulating factor (hG-CSF) expression in milk during induced lactation. Six female Canindé goats-three transgenic (T) and three non-transgenic (NT)-were subjected to hormone therapy to induce lactation; ultrasonographic examinations of the liver, gallbladder, spleen, kidneys, and mammary gland were performed during both the hormonal therapy and the lactation period at different intervals depending on the organ being examined. On Day 16 (Day 1 = hormonal therapy initiation), all goats were lactating and presented healthy mammary glands, characterized by echogenic parenchyma showing a granular echotexture. Transgenic and nontransgenic goats were compared on the basis of measurements and ultrasound images obtained from each organ. No differences between T and NT animals were observed in the examined area for the liver, gallbladder, spleen, and kidneys. Liver and renal echogenicity and appearance of gallbladder and portal and hepatic veins were similar in all females. Ultrasonographic findings of the mammary gland, liver, gallbladder, spleen, and kidneys in transgenic goats did not show any difference from those in nontransgenic goats.Thus, these results suggest that the presence and expression of the transgene had no effect on the ultrasonographic findings of mammary gland and abdominal organs in the transgenic goats. Moreover, the findings shows that ultrasonography is a useful screening tool for clinical examination
\end{abstract}

${ }^{1}$ Prof., Instituto Federal de Educação, Ciência e Tecnologia, IFCE, Crateús, CE, Brasil. E-mail: francisco.sousa@ifce.edu.br

2 Prof., Instituto Superior de Teologia Aplicada, INTA, Sobral, CE, Brasil. E-mail: carlosousamelo@hotmail.com

${ }^{3}$ Pesquisador, Universidade Estadual do Ceará, UECE, Fortaleza, CE, Brasil. E-mail: ribrio@yahoo.com.br

4 Discente, UECE, Fortaleza, CE, Brasil. E-mail: dey1926@hotmail.com

5 Pesquisadora, UECE, Fortaleza, CE, Brasil. E-mail: joannavet@gmail.com

${ }^{6}$ Prof $^{\mathrm{a}}$, Universidade Federal Rural do Semi-Árido, UFERSA, Fortaleza, CE, Brasil. E-mail: alexsandra.pereira@ufersa.edu.br

7 Profs., UECE, Fortaleza, CE, Brasil. E-mail: lucianamelo.2005@gmail.com; vicente.freitas@uece.br; darcio.teixeira@uece.br

* Author for correspondence 
of transgenic goats; this allows the investigation of possible disorders and avoids the unnecessary use of invasive techniques.

Key words: Caprine. Transgenesis. Ultrasonography. Abdominal organs.

\section{Resumo}

Em camundongos transgênicos, o estudo de certos órgãos ou tecidos pode ser viabilizado por meio da eutanásia de alguns exemplares. Entretanto, esta prática pode não ser economicamente viável quando aplicada a animais de produção, como caprinos transgênicos. É necessário utilizar métodos minimamente invasivos para estudar in vivo os órgãos que podem estar envolvidos em desordens relacionadas à atividade do transgene, principalmente durante a produção de leite, quando a proteína recombinante é secretada. O objetivo deste estudo foi descrever as características ultrassonográficas de fígado, vesícula biliar, baço, rins e glândula mamária de caprinos transgênicos expressando o fator estimulante de colônias de granulócitos humano (hG-CSF) no leite, durante lactação induzida. Seis fêmeas caprinas da raça Canindé: três não transgênicas (NT) e três transgênicas (T) foram submetidas a tratamento hormonal para indução da lactação; os exames ultrassonográficos de fígado, vesícula biliar, baço, rins e glândula mamária foram realizados durante tratamento hormonal e lactação, em diferentes intervalos de acordo com o órgão. No dia 16 (Dia 1 = início do tratamento hormonal) todas as cabras estavam em lactação e apresentando uma glândula mamária saudável, caracterizada por parênquima ecogênico, com uma ecotextura granular. As cabras T e NT foram comparadas em relação às mensurações e aparência ultrassonográfica obtida de cada órgão. Não foram observadas diferenças com relação à área para exame de fígado, vesícula biliar, baço e rins entre T e NT. A ecogenicidade de fígado e rins, a aparência da vesícula biliar e das veias porta e hepática foram similares em todas as fêmeas. As mensurações ultrassonográficas dos órgãos abdominais examinados não revelaram diferenças entre animais T e NT. Assim, esses resultados sugerem que a presença e expressão do transgene não tiveram efeito sobre as características ultrassonográficas de glândula mamária e órgãos abdominais nos animais transgênicos. Além disso, os achados mostram que a ultrassonografia é uma importante ferramenta para o exame clínico em caprinos transgênicos e que permite a investigação de possíveis desordens, evitando o uso desnecessário de técnicas invasivas.

Palavras-chave: Caprino. Transgênese. Ultrassonografia. Órgãos abdominais.

\section{Introduction}

The human granulocyte-colony stimulating factor (hG-CSF) protein plays a crucial role in neutrophil-based immune reactions This is because it regulates the growth, differentiation, survival, and activation of neutrophils and their precursors (BARREDA et al., 2004). However, most of the existing studies for recombinant hG-CSF refer to murine species and only one describes a study on transgenic goats (KO et al., 2000). Recently, we produced two founder goats and its F1 offspring able to produce hG-CSF in milk (FREITAS et al., 2012; MOURA et al., 2013). Nevertheless, literature about studies on transgenic livestock health is scarce.
In transgenic murine models, the study of certain organs or tissues can be performed after euthanasia of some specimens. However, this practice may not be economically feasible when applied to livestock such as transgenic goats. Therefore, it is necessary to use minimally invasive methods to perform in vivo studies of organs that may be affected by disorders related to the activity of the transgene, particularly during milk production, when the recombinant protein is secreted.

Currently, ultrasound has been successfully used in goats to evaluate the morphology of different internal organs including liver (ACORDA et al., 2006), spleen (ACORDA et al., 2009a), and kidneys (ACORDA et al., 2005; ROSSI et al., 2012). The aim of this study was to describe the ultrasonographic 
findings of the mammary gland, liver, gallbladder, spleen, and kidneys in transgenic (T) goats for hG-CSF compared with non-transgenic (NT) ones during induced lactation.

\section{Material and Methods}

\section{Ethics and biosafety}

All protocols used in this work were approved by the Animal Ethics Committee of the State University of Ceará (Protocol no. 12237085-6) and the Brazilian Biosafety Technical National Committee (CTNBio 228/06). Additionally, all studies were conducted according to the guidelines for the ethical use of animals in research (ASAB, 2012).

\section{Location and experimental animals}

The experiment was performed in the Laboratory of Physiology and Control of Reproduction, located in Fortaleza-CE, Brazil, $3^{\circ} 47^{\prime} 38^{\prime \prime} \mathrm{S}$ and $38^{\circ} 33^{\prime}$ 29" W. For this trial, six female Canindé goats F1 transgenic for hG-CSF $(\mathrm{n}=3)$ and non-transgenic $(\mathrm{n}=3)$, aged $\sim 10$ months and weighing $\sim 23 \mathrm{~kg}$ were studied. Goats were housed indoors and maintained in a semi-intensive system; they were provided Tifton (Cynodon dactylon) hay in pens and had $4 \mathrm{~h}$ of daily access to a solarium. In addition, the animals were given supplements in the form of a commercial concentrate containing $20 \%$ of crude protein (Caprino Top, Integral Mix, Fortaleza, CE, Brazil). They also had unrestricted access to water and mineralized salt.

\section{Induced lactation}

For induction of lactation, we used a hormonal therapy for goats previously described by Cammuso et al. (2000). On Day 1 (hormonal therapy initiation), $0.25 \mathrm{mg} / \mathrm{kg}$ estradiol cypionate (Ouro Fino Saúde Animal, Cravinhos, SP, Brazil) and 0.75 $\mathrm{mg} / \mathrm{kg}$ progesterone (Hertape Calier Saúde Animal, Juatuba, SP, Brazil) were administered to goats by intramuscular injection. Estrogen and progesterone were injected every other day for seven days (Days $1,3,5,7,9,11$, and 13). From Day 14 to $16,0.4 \mathrm{mg}$ / kg prednisolone (Laboratórios König, Avellaneda, BA, Argentina) was administered daily. From day 5, external massage of the mammary gland was performed daily for $5 \mathrm{~min}$ on each female to stimulate lactogenesis; this was continued until milk production was observed. Animals were then handmilked daily and individual volumes were recorded.

\section{Ultrasonographic procedure and image analysis}

Ultrasound examinations were conducted using a dual frequency convex-array transducer of 3.5/5.0 MHz coupled to a B-mode Falco Vet 100 apparatus (Pie-Medical, Maastricht, Netherlands). Ultrasound configurations such as overall gain, far gain, near gain, and focus were adjusted according to the characteristics of the organ examined.

Goats were handled using gentle physical restraint, and their abdominal and thoracic skin was shaved. Ultrasound gel was applied to their skin and to the transducer. The examination was performed on non-sedated goats after overnight fasting; the goats were in standing position during the procedure. To reduce the time required for the examinations, all ultrasonographic procedures were recorded on video and analyzed retrospectively (SOUSA et al., 2011). All examinations were performed by only one operator who had been trained previously. On recorded images, subjective ultrasonographic evaluation was performed through codes associated to T or NT goats, using the software Image J $1.45 \mathrm{~s}$ (National Institutes of Health, Millersville, PA, USA). Ultrasonography of the liver, gallbladder, spleen, and kidneys were performed on alternate days during the induced lactation period. Once milk production was achieved, these examinations were performed at weekly intervals, until that lactation stopped. 


\section{Ultrasonography of mammary gland}

For evaluation of the mammary gland, ultrasonographic technique used was in direct contact (transcutaneous ultrasonography), according to Melo et al. (2012). Mammary gland examinations were performed everyday immediately before milking, from the $1^{\text {st }}$ to the $17^{\text {th }}$ day of lactation. After this period, examinations were conducted on alternate days until cessation of lactation. The echogenicity of the mammary gland parenchyma was evaluated in ultrasonograms; measurements of area and greater and shorter lengths of the gland cistern were calculated.

\section{Ultrasonography of liver and gallbladder}

Liver examination was performed by placing the transducer in the right flank of the animal, in a caudal-to-cranial direction [from the last rib to the $6^{\text {th }}$ intercostal space (ICS)] as earlier described (BRAUN; STEININGER, 2011). The area to be examined on the liver imaging was determined. The appearance of liver parenchyma, blood vessels, and gallbladder were subjectively assessed by ultrasound. Concerning the liver, the appearance of the organ surface, the echogenicity, and homogeneity of the hepatic parenchyma were recorded. Hepatic blood vessels and the caudal vena cava were visualized and their appearance was evaluated. Liver width measurement was done from the dorsal to the ventral margin in the image containing the greatest visible parenchyma. Liver width was measured at expiration when the hepatic contour was clearly defined. The area for examination, shape, length, and width of the gallbladder were determined.

\section{Ultrasonography of spleen}

To evaluate the spleen, the transducer was placed in the dorsal region of animal's left flank in the caudal-to-cranial direction starting from the last lumbar vertebra on the paralumbar fossa to the $6^{\text {th }}$ ICS (ACORDA et al., 2009a). The area for examination of the spleen on the left flank was determined. The appearance of the splenic capsule and parenchyma were subjectively assessed. In the image that contained the greatest visible parenchyma, spleen width was measured from the dorsal to the ventral margin; in the same image, spleen length was determined from the cranial to the caudal margin.

\section{Ultrasonography of kidneys}

Visualization of both kidneys was performed using a methodology similar to that used in previous studies in sheep (ACORDA et al., 2009b). The transducer was placed in the dorsal region of the right flank, starting from the last lumbar vertebra on the paralumbar fossa to the $10^{\text {th }}$ ICS. The area for examination of both kidneys was identified. Transverse and longitudinal renal ultrasonograms were obtained from different sites and ultrasound appearance of various renal structures was evaluated. The echogenicity of the different renal structures was also recorded. The kidney length was expressed as the distance between cranial and caudal renal poles (measured in the longitudinal plane). The kidney width was expressed as the distance between ventral and dorsal surfaces (measured in the transverse plane at the level of renal pelvis) (BRAUN et al., 1992).

\section{Statistical analysis}

Transgenic and non-transgenic goats were compared on the basis of measurements and ultrasound images obtained from each organ. To evaluate the data, the normality KolmogorovSmirnov test was employed. Data showing normal distribution were analyzed by paired $t$-test. For non-normally distributed data, the Mann-WhitneyWilcoxon test was used. The relationship between the average area of gland cistern and milk production was plotted as linear regression and expressed as a straight-line equation. Values were expressed as 
mean \pm SEM, and differences were considered to be statistically significant at a level of $P<0.05$. Statistical analysis was performed using GraphPad InStat 3.0 (GraphPad Software, San Diego, USA).

\section{Results and Discussion}

The main objective of the present study was to describe the ultrasonographic findings of the mammary gland, liver, gallbladder, spleen, and kidneys during induced lactation in $\mathrm{T}$ goats that are able to produce hG-CSF in milk. Data concerning dimensions of liver, gallbladder, spleen, and kidneys are presented in Table 1. No differences $(P>0.05)$ were observed between $\mathrm{T}(\mathrm{n}=3)$ and NT $(\mathrm{n}=3)$ animals in the analysis of 336 ultrasonographic images of abdominal organs (Figure 1). Previous studies have validated ultrasonography as a reliable investigative method in goats since its results were further confirmed by post mortem examinations (ACORDA et al., 2005, 2006). All these data showed that ultrasonography is a useful and noninvasive technique to detect possible disorders in $\mathrm{T}$ goats.

Table 1. Measurements obtained from ultrasonographic images of liver, gallbladder, spleen, and kidneys in transgenic and non-transgenic goats.

\begin{tabular}{|c|c|c|c|c|}
\hline \multirow{2}{*}{ Organ } & \multirow{2}{*}{ Variable } & \multicolumn{2}{|c|}{ Measurements $(\mathrm{cm})^{1}$} & \multirow{2}{*}{$P$ value } \\
\hline & & $\mathrm{T}$ & NT & \\
\hline \multirow[t]{2}{*}{ Liver } & Width & $5.5 \pm 0.2$ & $5.3 \pm 0.1$ & 0.24 \\
\hline & Area $^{2}$ & $1.0 \pm 0.1$ & $1.1 \pm 0.1$ & 0.20 \\
\hline \multirow[t]{2}{*}{ Gallbladder } & Length & $1.6 \pm 0.1$ & $1.5 \pm 0.1$ & 0.49 \\
\hline & Width & $0.7 \pm 0.0$ & $0.7 \pm 0.0$ & 0.36 \\
\hline \multirow{2}{*}{ Spleen } & Width & $1.7 \pm 0.1$ & $1.7 \pm 0.0$ & 0.72 \\
\hline & Length & $4.7 \pm 0.2$ & $4.9 \pm 0.2$ & 0.44 \\
\hline \multirow{2}{*}{ Right kidney } & Length & $5.3 \pm 0.1$ & $5.5 \pm 0.1$ & 0.35 \\
\hline & Width & $2.5 \pm 0.0$ & $2.6 \pm 0.0$ & 0.22 \\
\hline \multirow{2}{*}{ Left kidney } & Length & $5.7 \pm 0.1$ & $5.8 \pm 0.1$ & 0.52 \\
\hline & Width & $2.7 \pm 0.0$ & $2.9 \pm 0.0$ & 0.10 \\
\hline
\end{tabular}

${ }^{1}$ Organ measurements are presented as mean \pm SEM for transgenic (T) and non-transgenic (NT) goats. ${ }^{2}$ Area unit in $\mathrm{cm}^{2}$.

One transgenic goat started lactation on Day 10; on Day 16 of hormonal therapy, all the remaining goats also started lactating. Lactation stopped after four months. The average milk production was $\sim 19$ $\mathrm{mL}$ per day for $\mathrm{T}$ and $\sim 39 \mathrm{~mL}$ per day for NT female goats in the first month. The hormonal therapy used in the present study was $100 \%$ effective for inducing lactogenesis; this result was slightly greater than the $95 \%$ effectiveness previously obtained in goats (MELLADO et al., 1996). In addition, the lactation started in the expected time period (Day 16) (CAMMUSO et al., 2000). 
Figure 1. Ultrasonograms of liver (a and a'), spleen ( $b$ and b'), and kidneys (c and c') in transgenic (a, b, and c) and non-transgenic (a', b', and c') goats. Liver (L), caudal vena cava (arrow), gallbladder (asterisk), spleen (S), cortex (C), pelvis $(\mathrm{P})$, and medulla $(\mathrm{M})$.

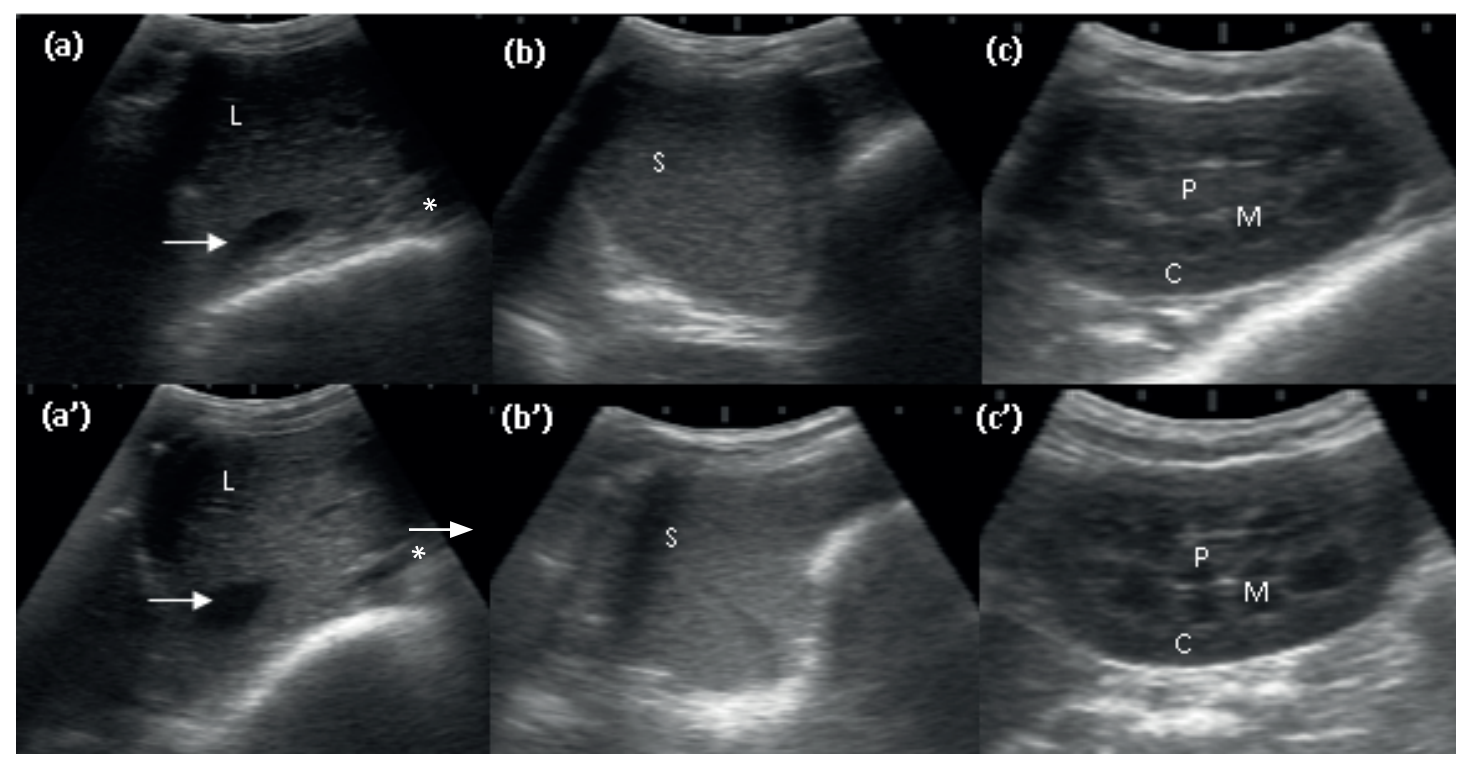

On the 358 images of mammary glands with echogenic particles. The large lactiferous ducts examined, the parenchyma was uniformly within the cisterns were clearly perceptible and echogenic with a granular echotexture (Figure 2). This typical image is the result of connective tissue and gland parenchyma having higher and lesser echogenic density, respectively. Milk secretion in the gland cistern resulted in an anechogenic image showed anechogenicity, which was also noticed in other studies (FASULKOV et al., 2010). A similar ultrasonographic appearance of lactating mammary gland was previously described by us in T and NT goats (MELO et al., 2012).

Figure 2. Ultrasonograms of mammary glands in transgenic (a) and non-transgenic (b) goats during induced lactation. Sonograms were recorded at Day 15 of lactation. White arrow: gland cistern; yellow arrow: gland parenchyma.

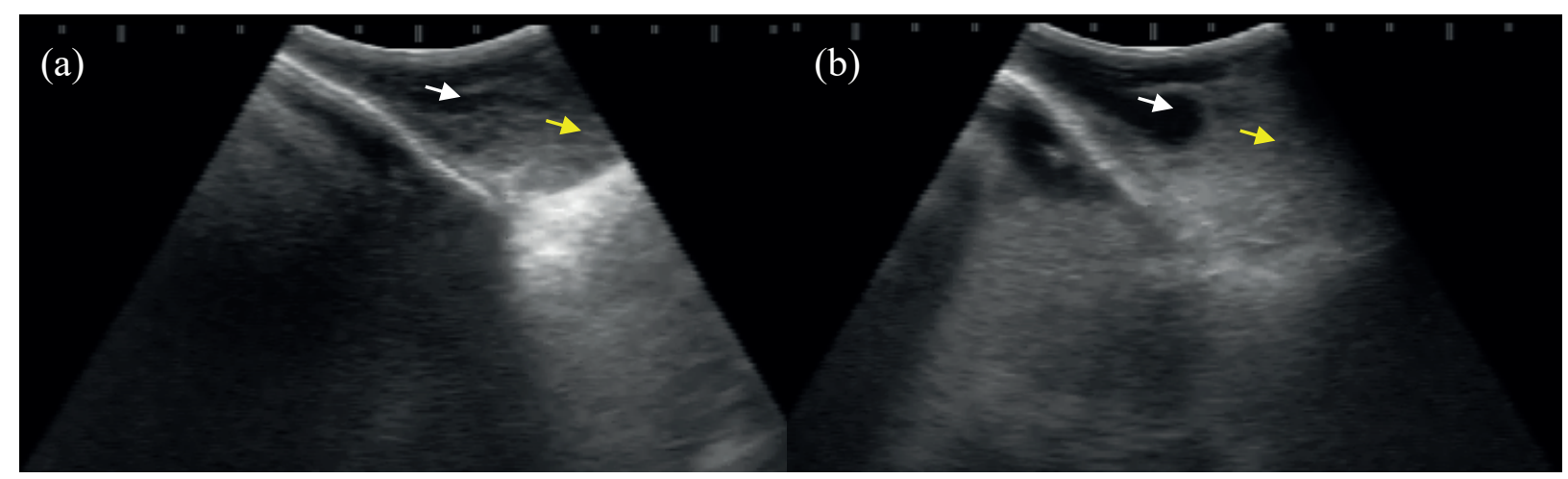

In the widest section, detailed measurements of the gland cistern size were determined. Mean values $( \pm$ SEM) for area, length, and width of the gland cistern were, respectively, $4.0 \pm 0.3 \mathrm{~cm}^{2}, 3.1$ 
$\pm 0.1 \mathrm{~cm}$, and $1.1 \pm 0.0 \mathrm{~cm}$ for $\mathrm{T}$ goats and $5.5 \pm 0.3$ $\mathrm{cm}^{2}, 3.6 \pm 0.1 \mathrm{~cm}$, and $1.7 \pm 0.0 \mathrm{~cm}$ for NT goats. The relationship between the cistern area (Y) and milk yield $(\mathrm{X})$ was expressed as a linear correlation curve, with a correlation coefficient significantly positive for both $\mathrm{T}(\mathrm{Y}=0.1266 \mathrm{X}+3.9144 ; \mathrm{r}=0.8$; $P<0.0001)$ and NT $(\mathrm{Y}=0.0526 \mathrm{X}+5.4551 ; \mathrm{r}=0.8$; $P<0.0001)$ animals.

Several studies have used ultrasonography to determine the cistern size of the ruminant mammary gland and its relationship with milk yield. The main ultrasonographic parameters used to estimate milk yield in ruminants are length, width, and cistern area (AYADI et al., 2003; NUDDA et al., 2000). In the current study, a high positive correlation coefficient between cistern area and milk yield was observed in both T and NT ( $\mathrm{r}=0.8)$ goats, similar to the value obtained $(\mathrm{r}=0.9)$ in Polish White goats (WÓJTOWSKI et al., 2002).

The liver could be imaged from the $7^{\text {th }}$ ICS to the $13^{\text {th }}$ rib in the right flank of T and NT goats. The largest visible extent of liver was from the $8^{\text {th }}$ to the $12^{\text {th }}$ ICS. This was the area considered for examination and was in accordance with previous reports in goats (KANDEEL et al., 2009). The liver was thinnest in the $7^{\text {th }}$ ICS and $13^{\text {th }} \mathrm{rib}$, as demonstrated for Saanen goats (BRAUN; STEININGER, 2011). Hepatic parenchyma and the right kidney were visualized caudally to the $13^{\text {th }}$ rib on the same image.

The parenchyma pattern of the liver was characterized by hypoechogenicity; numerous weak echoes were clearly present and homogeneously distributed over the entire area of the liver. However, it had a higher echogenicity in comparison with the renal cortex. In all the female goats, the diaphragmatic surface of the liver appeared as a smooth and narrow echogenic line, which was located immediately adjacent to the peritoneum and moved in synchrony with the diaphragm during breathing. In the present study, the appearance of hepatic parenchyma was the same as described in previous reports in goats (KANDEEL et al., 2009), sheep (ACORDA et al., 2006), and bovine animals (IMRAN et al., 2011; RIZZO et al., 2014). Several common diseases in goats, such as fluke infestation and pregnancy toxemia, primarily involve the liver and may cause considerable economic loss of livestock. Additionally, ultrasonography can be helpful in identifying uncommon masses, such as abscesses, hydatid cysts, and neoplasms (ACORDA et al., 2009a).

The liver vasculature was represented by anechogenic lumen structures and the portal vein by hyperechogenic walls; the hepatic vein walls were not detected. The caudal vena cava was characterized by anechogenic lumen with thin and echogenic walls. In general, the caudal vena cava presents a triangular shape in cross sections, but the cross section of portal vein is circular. Both longitudinal and cross sectional segments of these vessels could be identified. It was not possible to detect the bile ducts in the liver parenchyma. Neither the caudal vena cava nor hepatic vessels showed any changes; their appearance was in agreement with that described in earlier reports in Saanen goats (BRAUN; STEININGER, 2011). The nondetectability of the bile ducts on ultrasonograms was expected in goats, according to Kandeel et al. (2009). Thus, these structures were considered normal in all studied animals.

The gallbladder was visualized in all T and NT goats. It was visible in the $9^{\text {th }}, 10^{\text {th }}$, or in both ICS in the ventral area of the right flank. It appeared as a fluid-filled vesicle with variable shape (from round to pyriform shape), anechogenic lumen, and echogenic walls. No significant differences were observed in gallbladder dimensions between $\mathrm{T}$ and NT animals. The gallbladder interior and its wall were checked for the presence of pathologic conditions, particularly calculi, obstructions, and foreign mass in the anechogenic lumen (ACORDA et al., 2006). Its area for examination and appearance were similar to that in earlier reports on goats and sheep (ACORDA et al., 2009b; 
BRAUN; STEININGER, 2011; KANDEEL et al., 2009). A smaller gallbladder length was observed in comparison with Saanen goats $(4.5 \mathrm{~cm})$ (BRAUN; STEININGER, 2011), probably because of the smaller size of Canindé female goats. Moreover, gallbladder dimensions may vary with its degree of fullness, which is dependent on the bile volume. In the current study, no abnormalities in the gallbladder lumen and wall were observed between $\mathrm{T}$ and NT goats.

With respect to the spleen, it was easily identified on the upper left abdominal wall between the $10^{\text {th }}$ and the $12^{\text {th }}$ ICS. In T animals, the spleen was extended to the region immediately caudal to the $13^{\text {th }}$ rib. Splenic structures such as vein, parenchyma, and capsule were identified. A highly echogenic capsule appeared marking the distal border of the spleen; this highlighted its visualization. The splenic parenchyma consisted of numerous weak echoes homogeneously distributed throughout the visible extent of the organ. The splenic vein was observed internally in the parenchyma; it had an anechogenic lumen with hypoechogenic walls and appeared tubular in shape. The splenic hilum was not visible. In addition, no significant differences were observed in the spleen length between $\mathrm{T}(4.7 \pm 0.2 \mathrm{~cm})$ and NT $(4.9 \pm 0.2 \mathrm{~cm})$ goats.

In $\mathrm{T}$ goats, the spleen was slightly extended caudal to the last rib. This result does not suggest splenomegaly and is consistent with that reported in 14 out of 30 Saanen goats in another report (BRAUN; STEININGER, 2010). This variability of the splenic position could be attributed to breathing movements during ultrasound examination. The ultrasonographic splenic appearance was similar to that described for Philippine native goats (ACORDA et al., 2009a) and cattle (IMRAN et al., 2011). Splenic hilum was not visible on ultrasonograms because it was superimposed by the lung. In the current trial, the spleen width did not differ between $\mathrm{T}$ and NT female goats $(\sim 1.7 \mathrm{~cm})$ and from that obtained in previous studies in native goats $(1.9 \mathrm{~cm})$ (ACORDA et al., 2009a).

Visualization of the right kidney was achieved by placing the transducer in the dorsal region of the right flank, and the area for obtaining the best image was from the caudal region to the last rib, near to the midline of the abdominal wall. The left kidney was located in the paralumbar fossa of the right flank and caudal to the right kidney. In general, kidneys appeared to have a horseshoe shape. The renal capsule was seen as a thin hyperechogenic line surrounding the kidney, and both renal cortex and renal pelvis also appeared hyperechogenic. Conversely, the renal medulla appeared hypoechogenic, being located between the cortex and pelvis. The medullary pyramids were identified as hypoechogenic circular structures.

Acorda et al. (2005) reported that only the right kidney was visualized by ultrasonography in goats. Sisson and Grossman (1975) stated that when the rumen is full, the left kidney usually lies entirely to the right of the median plane. In normal Saanen goats, Rossi et al. (2012) demonstrated that the left kidney was viewed caudally to the right kidney in the same horizontal plane. Likewise, in the current trial, both kidneys were visualized in the right flank of the animals. The echogenicity of renal structures was consistent with that previously observed in goats (ACORDA et al., 2005) and sheep (ACORDA et al., 2009b).

The kidney length and width measured in the present trial are in accordance with those described for Philippine native goats (ACORDA et al., 2005). Interestingly, a length of 7.1 to $8.9 \mathrm{~cm}$ and a width of 3.3 to $4.7 \mathrm{~cm}$ were observed by Braun et al. (1992) in sheep, possibly due to their larger size and weight (41-89 $\mathrm{kg}$ for sheep $v s . \sim 23 \mathrm{~kg}$ for Canindé goats). According to El-Kammar et al. (2012), hydronephrosis and kidney enlargement can be diagnosed by ultrasonography. However, in our study, no changes in the ultrasonographic image of kidneys were observed in T or NT goats. 
The evaluation of the transgenic animal health is an important aspect for defining the safety of the application of transgenic technology to livestock production and human medicine. However, specific studies focusing on the health and welfare of transgenic livestock are lacking in the literature. Breeding and maintaining transgenic animals in case of murine species is more convenient; in contrast, the number of live animals when studying livestock such as goats is small, and euthanasia of these transgenic specimens for studying certain organs or tissues is not feasible.

\section{Conclusion}

Ultrasonographic findings of the mammary gland, liver, gallbladder, spleen, and kidneys in transgenic goats did not show any difference from those in non-transgenic goats. These results suggest that the ultrasonographic findings of mammary gland and abdominal organs in the transgenic female goats were not affected by the presence and expression of the transgene. Moreover, the results shows that ultrasonography is a useful screening tool for clinical examination of transgenic goats, which allows the investigation of possible disorders and avoids the unnecessary use of invasive techniques.

\section{Acknowledgments}

The authors wish to thank the staff of the Laboratory of Physiology and Control of Reproduction for technical assistance and animal care. Conselho Nacional de Desenvolvimento Científico e Tecnológico (CNPq, Brasília, Brazil), Coordenação de Aperfeiçoamento de Pessoal de Nível Superior (CAPES, Brasília, Brazil), and Fundação Cearense de Apoio ao Desenvolvimento Científico e Tecnológico (FUNCAP, Ceará, Brazil) supported this work by supplying student and postdoc grants. Vicente J.F. Freitas is a CNPq senior investigator.

\section{Declaration of interest}

The authors declare that there is no conflict of interest.

\section{References}

ACORDA, J. A.; ACEBEDO, M. C.; MALIGAYA, R. L. Ultrasonographic features of the liver and associated structures in Philippine native goats (Capra hircus). Philippine Journal of Veterinary Medicine, Philippines, v. 43, n. 1, p. 1-7, 2006.

ACORDA, J. A.; ANCHETA, M. N.; DETERA, M. A. J.; CABRERA, L. A.; MALIGAYA, R. L. Comparative ultrasound features and echo histograms of the spleen in female goats (Capra hircus), sheep (Ovis aries) and buffaloes (Bubalus bubalis). Philippine Journal of Veterinary Medicine, Philippines, v. 35, n. 2, p. 135-146, 2009a.

ACORDA, J. A.; PALOMA, J. C.; CARIASO, W. E.; CABRERA, L. A. Comparative ultrasound features of the liver, kidneys and spleen in female sheep (Ovis aries) at different ages. Philippine Journal of Veterinary Medicine, Philippines, v. 46, n. 1, p. 26-36, 2009b.

ACORDA, J. A.; VERGARA, M. E. M.; MALIGAYA, R. L. Ultrasonographic examination of the kidneys in Philippine native goats (Capra hircus). Philippine Journal of Veterinary Medicine, Philippines, v. 42, n. 1, p. 9-15, 2005.

ASSOCIATION FOR THE STUDY OF ANIMAL BEHAVIOUR - ASAB. Guidelines for the treatment of animals in behavioral research and teaching. Animal Behaviour, London, v. 83, n. 1, p. 301-309, 2012.

AYADI, M.; CAJA, G.; SUCH, X.; KNIGHT, C. H. Use of ultrasonography to estimate cistern size and milk storage at different milking intervals in the udder of dairy cows. Journal of Dairy Research, London, v. 70, n. 1, p. 1-7, 2003.

BARREDA, D.; HANINGTON, P.; BELOSEVIC, M. Regulation of myeloid development and function by colony stimulating factors. Developmental \& Comparative Immunology, Los Angeles, v. 28, n. 5, p. 509-554, 2004.

BRAUN, U.; GERBER, D.; SCHEFER, U. Ultrasonography of the urinary tract of female sheep. American Journal of Veterinary Research, Schaumburg, v. 53, n. 10, p. 1734-1739, 1992.

BRAUN, U.; STEININGER, K. Ultrasonographic characterization of the liver, caudal vena cava, portal 
vein, and gallbladder in goats. American Journal of Veterinary Research, Schaumburg, v. 72, n. 2, p. 219225, 2011.

BRAUN, U.; STEININGER, K. Ultrasonographic examination of the spleen in 30 goats. Schweizer Archiv für Tierheilkund, Postfach, v. 152, n. 10, p. 477-481, 2010.

CAMMUSO, C.; PORTER, C.; NIMS, S.; GAUCHER, D.; MELICAN, D.; BOMBARD, S.; HAWKINS, N.; O'COIN, A.; RICCI, C.; BRAYMAN, C.; BUZZELL, N.; ZIOMEK, C.; GAVIN, W. Hormonal induced lactation in transgenic goats. Animal Biotechnology, Philadelphia, v. 11, n. 1, p. 1-17, 2000.

EL-KAMMAR, M. H.; ALSAFY, M. A. M.; MOHAMMED, M. I.; EL-NEWESHY, M. S. Ureteric obstruction and hydronephrosis in Baladi goats: topographical anatomy, ultrasonographical, hematological and pathological findings. Small Ruminant Research, Bloemfontein, v. 104, n. 1-3, p. 169-178, 2012.

FASULKOV, I. R.; GEORGIEV, P. I.; ANTONOV, A. L.; ATANASOV, A. S. B-mode ultrasonography of mammary glands in goats during the lactation period. Bulgarian Journal of Veterinary Medicine, Stara Zagora, v. 13, n. 4, p. 245-251, 2010.

FREITAS, V. J. F.; SEROVA, I. A.; MOURA, R. R.; ANDREEVA, L. E.; MELO, L. M.; TEIXEIRA, D. Í. A.; PEREIRA, A. F.; LOPES JÚNIOR, E. S.; DIAS, L. P. B.; NUNES-PINHEIRO, D. C. S.; SOUSA, F. C.; ALCÂNTARA-NETO, A. S.; ALBUQUERQUE, E. S.; MELO, C. H. S.; RODRIGUES, V. H. V.; BATISTA, R. I. T. P.; DVORYANCHIKOV, G. A.; SEROV, O. L. The establishment of two transgenic goat lines for mammary gland hG-CSF expression. Small Ruminant Research, Bloemfontein, v. 105, n. 1-3, p. 105-113, 2012.

IMRAN, S.; TYAGI, S. P.; KUMAR, A.; KUMAR, A.; SHARMA, S. Comparative ultrasonographic imaging of spleen and liver in healthy crossbred cows. International Scholarly Research Network, New York, v. 2011, n. 2011, p. 1-7, 2011.

KANDEEL, A. E.; OMAR, M. S. A.; NEFISSA, H. M. M.; EL-SEDDAWY, F. D.; GOMAA, M. Anatomical and ultrasonographic study of the stomach and liver in sheep and goats. Iraqi Journal of Veterinary Sciences, Mosul, v. 23, n. 2, p. 181-191, 2009.

KO, J. H.; LEE, C. S.; KIM, K. H.; PANG, M. G.; KOO, J. S.; FANG, N.; KOO, D. B.; OH, K. B.; YOUN, W. S.; ZHENG, G. D.; PARK, J. S.; KIM, S. J.; HAN, Y. M.; CHOI, I. Y.; LIM, J.; SHIN, S. T.; JIN, S. W.; LEE, K. K.; YOO, O. J. Production of biologically active human granulocyte colony stimulating factor in the milk of transgenic goat. Transgenic Research, London, v. 9, n. 3, p. 215-222, 2000.

MELLADO, M.; BERNAL, A.; MENDOZA, R.; CARRILLO, E. Hormonal induction of lactation in prepuberal and multiparous crossbred goats kept under extensive conditions. Small Ruminant Research, Bloemfontein, v. 19, n. 2, p. 143-147, 1996.

MELO, C. H. S.; SOUSA, F. C.; TELES FILHO, A. C. A.; MOURA, R. R.; ALBUQUERQUE, E. S.; PEREIRA, A. F.; MELO, L. M.; FREITAS, V. J. F.; TEIXEIRA, D. Í. A. Mensurações ultrassonográficas da cisterna da glândula mamária de caprino transgênico. Arquivo Brasileiro de Medicina Veterinária e Zootecnia, Belo Horizonte, v. 64, n. 2, p. 491-494, 2012.

MOURA, R. R.; ALBUQUERQUE, E. S.; MELO, C. H. S.; ALCÂNTARA NETO, A. S.; BATISTA, R. I. T. P.; NUNES-PINHEIRO, D. C. S.; PEREIRA, A. F.; TEIXEIRA, D. I. A.; MELO, L. M.; SEROVA, I. A.; ANDREEVA, L. E.; SEROV, O. L.; FREITAS, V. J. F. Dynamics of recombinant hG-CSF in transgenic goat: preliminary study in the founder during hormonally induced lactation. Animal Biotechnology, Philadelphia, v. 24 , n. 1, p. 10-14, 2013.

NUDDA, A.; PULINA, G.; VALLEBELLA, R.; BENCINI, R.; ENNE, G. Ultrasound technique for measuring mammary cistern size of dairy ewes. Journal of Dairy Research, London, v. 67, n. 1, p. 101-106, 2000.

RIZZO, H.; ROSSI, R. S.; MEIRA JUNIOR, E. B. S.; RAMALHO, N. P.; RIBEIRO, B. L. M.; GREGORY, L. Uso do ultrassom em bovinos com enfermidades intestinais e dos anexos do tubo digestivo. Ciência Animal (UECE), Fortaleza, v. 24, n. 1, p. 46-61, 2014.

ROSSI, R. S.; BOMBONATO, P. P.; PIVA, F. M.; GREGORY, L. Avaliação da morfometria renal através do método ultrassonográfico de fêmeas caprinas (Capra hircus) normais da raça Saanen. Pesquisa Veterinária Brasileira, Rio de Janeiro, v. 32, n. 2, p. 165-173, 2012.

SISSON, S.; GROSSMAN, J. D. The anatomy of the domestic animals. Philadelphia: WB Saunders Company, 1975. $2000 \mathrm{p}$.

SOUSA, F. C.; MELO, C. H. S.; TELES FILHO, A. C. A.; AVELAR, S. R. G.; MOURA, A. A. A.; MARTINS, J. A. M.; FREITAS, V. J. F.; TEIXEIRA, D. I. A. Ovarian follicular response to different hormonal stimulation treatments in Canindé goats. Animal Reproduction Science, Werribee, v. 125, n. 1-4, p. 88-93, 2011.

WÓJTOWSKI, J.; LÓSARZ, P.; GÓRECKI, M.; MALECHA, W. Ultrasound measurements of goat's mammary gland cisterns during lactation. Medycyna Wetrynaryjna, Lublin, v. 58, n. 12, p. 977-998, 2002. 